\title{
Alliances and the innovation performance of corporate and public research spin-off firms
}

Citation for published version (APA):

Hagedoorn, J., Lokshin, B., \& Malo, S. (2016). Alliances and the innovation performance of corporate and public research spin-off firms. Maastricht University, Graduate School of Business and Economics. GSBE Research Memoranda No. 041 https://doi.org/10.26481/umagsb.2016041

Document status and date:

Published: 01/01/2016

DOI:

10.26481/umagsb.2016041

Document Version:

Publisher's PDF, also known as Version of record

\section{Please check the document version of this publication:}

- A submitted manuscript is the version of the article upon submission and before peer-review. There can be important differences between the submitted version and the official published version of record.

People interested in the research are advised to contact the author for the final version of the publication, or visit the DOI to the publisher's website.

- The final author version and the galley proof are versions of the publication after peer review.

- The final published version features the final layout of the paper including the volume, issue and page numbers.

Link to publication

\footnotetext{
General rights rights.

- You may freely distribute the URL identifying the publication in the public portal. please follow below link for the End User Agreement:

www.umlib.nl/taverne-license

Take down policy

If you believe that this document breaches copyright please contact us at:

repository@maastrichtuniversity.nl

providing details and we will investigate your claim.
}

Copyright and moral rights for the publications made accessible in the public portal are retained by the authors and/or other copyright owners and it is a condition of accessing publications that users recognise and abide by the legal requirements associated with these

- Users may download and print one copy of any publication from the public portal for the purpose of private study or research.

- You may not further distribute the material or use it for any profit-making activity or commercial gain

If the publication is distributed under the terms of Article $25 \mathrm{fa}$ of the Dutch Copyright Act, indicated by the "Taverne" license above, 
John Hagedoorn, Boris Lokshin, Stéphane Malo

Alliances and the innovation performance of corporate and public research spin-off firms

RM/16/041

\section{GSBE}

Maastricht University School of Business and Economics

Graduate School of Business and Economics

P.O Box 616

NL- 6200 MD Maastricht

The Netherlands 


\title{
ALLIANCES AND THE INNOVATION PERFORMANCE OF CORPORATE AND PUBLIC RESEARCH SPIN-OFF FIRMS
}

\author{
John Hagedoorn \\ Royal Holloway University of London and UNU-MERIT \\ John.Hagedoorn@ rhul.ac.uk and j.hagedoorn@maastrichtuniversity.nl \\ Boris Lokshin \\ Maastricht University \\ b.lokshin@maastrichtuniversity.nl \\ Stéphane Malo \\ American University of Paris \\ s.malo@aup.edu
}

Paper re-submitted to special issue of Small Business Economics on

'Economics and Strategy of Entrepreneurial Networks'

Earlier version of this paper was presented at the ZEW/MaCCI 2015 Conference in Mannheim, DRUID 2016 conference in Copenhagen, the EARIE 2016 conference in Lisbon and the 2016 British Academy of Management conference in Newcastle where this paper received a best full paper award.

Key words: alliances, spin-offs, entrepreneurial firms, innovation performance

JEL codes: L24, L26, L65, M13, O32 


\title{
ALLIANCES AND THE INNOVATION PERFORMANCE OF CORPORATE AND PUBLIC RESEARCH SPIN-OFF FIRMS
}

\begin{abstract}
We explore the innovation performance benefits of alliances for spin-off firms, in particular spin-offs from either other firms or from public research organizations. During the early years of the emerging combinatorial chemistry industry, the industry on which our empirical analysis focuses, spin-offs engaged in alliances with large and established partners, partners of similar type and size, and with public research organizations, often for different reasons. We seek to understand to what extent alliances of spin-offs with other firms (either large or small and medium sized firms) affected their innovation performance and also how this performance may have been affected by their corporate or public research background. We find evidence that in general alliances of spin-offs with other firms, in particular alliances with large firms, increased their innovation performance. Corporate spin-offs that formed alliances with other firms outperformed public research spin-offs with such alliances. This suggests that, in terms of their innovation performance, corporate spin-offs that engaged in alliances with other firms seemed to have benefitted from their prior corporate background. Interestingly, it turns out that the negative impact of alliances on the innovation performance of public research spin-offs was largely affected by their alliances with small and medium sized firms.
\end{abstract}

(word count: 200)

Key words: alliances, spin-offs, entrepreneurial firms, innovation performance JEL codes: L24, L26, L65, M13, O32

\section{INTRODUCTION}


Over the last two decades, globalization and increased competition has reshaped the innovation strategies of many firms towards a greater focus on external sources of knowledge (e.g. Archibugi and Michie 1995; OECD 2007). Internal sources of technological development alone are often insufficient to cope with the increasing intensity of competition as well as with the complexity and uncertainty of modern technologies. The alliance literature has well established that firms in technology-intensive industries are increasingly involved in various collaborations with heterogeneous partners, recognizing the crucial role of inter-firm networks and alliance portfolios in determining firms' innovation performance (e.g., George et al. 2001; Powell and Grodal 2005). Despite the wide recognition of alliances as a major vehicle for knowledge transfer and access to other firms' knowledge-based resources and capabilities (see also Mowery et al. 1996; Hagedoorn 1993), surprisingly, prior research gave limited attention to whether and how participation in inter-firm networks and formation of alliances affect the innovation performance of spin-offs, as a specific group of firms.

Notwithstanding this apparent omission, spin-off firms are worthwhile to study for several reasons. First, these firms are quite distinct from other (traditional) technological start-up firms in that they often have preferential access to valuable and difficult to imitate resources (Dahl and Sorenson 2014) and are more closely connected to their environment compared to other more loosely linked startups (Sedaitis 1998). Second, a substantial increase in the number of new firms as a result of spin-offs from existing firms and public research organizations, in particular in such sectors as biotechnology and information technology (Spin-Off Advisors, 2014), lead to a substantial academic and policy interest in these firms. Consequently, an important stream of literature has emerged since the early work by Cooper (1971) and Garvin (1983) that documents important positive contributions of spin-offs to economic value and growth. 
In this paper we contribute to the entrepreneurship literature on spin-offs by examining two related questions, i.e. 'why' and 'with whom' (with which categories of firms) participation in inter-firm alliance networks benefits the innovation performance of spin-off firms. In answering these two questions, we take a portfolio approach - a collection of all alliance links maintained by a focal firm - that serves as a vehicle for accessing and recombining knowledge to increase (innovation) performance (Wassmer, 2010). The potential benefits (the why question) of engaging in alliances derive from the notion that spinoffs in the combinatorial chemistry and biopharmaceutical industries operate in an environment characterized by strong technology and market uncertainties (Malo 2009; Santoro and McGill 2005). In addition, few, if any, spin-offs initially possess the comprehensive range of technological capabilities needed to stay innovative across a broad set of products and services (Forrest 1990). Consequently, forming alliances with other firms holds a promise for knowledge cross-fertilization, cumulative learning and facilitates spin-off firms to become more efficient in their technology-development activities (Clarysse, Heirman, Degroof 2000; Lechner, Dowling and Welpe 2006; Lockett, Siegel, Wright and Ensley 2005).

Given the specific nature of these firms, as young and technology-intensive but often lacking business acumen, we subsequently examine 'with whom' (i.e. large incumbent or similar-sized partners) the realization of the upside potential of alliances is most viable. We expect that the answer to this question partly depends on the formative nature of a spin-off itself. In addition to alternative alliance partner settings, we, therefore, also consider two major categories of spin-offs with very different backgrounds: corporate spin-offs (CSOs), firms that were spun-off (divested) by other firms, and public research spin-offs (PROs), firms that were spun-off (divested) by universities or public research organizations (Shane 2004; Helm and Mauroner 2007; Klepper 2009 for an overview). Prior research reveals 
significant differences between these two types of spin-off firms in such aspects as superior employment and sales growth of CSOs compared to PROs (e.g., Stankiewicz 1994; Callan 2001; Ensley and Hmieleski 2005; Yagüe-Perales and March-Chordà 2012; Zhang 2009). On the other hand, not much is known about the similarities or differences in the networking strategies of CSOs and PROs and how the underlying alliance choices made by these young, technology-intensive firms can help explain subsequent innovation performance differences between PROs and CSOs (cf., Lindholm-Dahlstrand 1997; Löfsten and Lindelöf 2005).

In addressing our research questions we draw on a knowledge conversion capability perspective (Boeker 1989; Zahra, Van Develde, Larrenta 2007) and integrate insights from two equally influent and informative schools of thought in the alliance literature that point at either the positive or the negative effects of asymmetric alliances involving young, relatively unestablished entrants and resource-abundant, large incumbent firms.

We test hypotheses in a unique, historical, empirical setting - a panel of 135 publicly traded spin-offs in the nascent field of combinatorial chemistry (i.e. an automated synthesis method capable of creating dozens, if not hundreds and thousands, of different molecules simultaneously for the purpose of discovering drugs, new materials, pesticides, etc.) during the years 1990 - 2003. As such, our research covers the crucial period of the emergence and gradual maturing of that industry (Thomke and Kuemmerle 2002), a period also characterized by high growth and increasing alliance activity of relevant spin-offs.

Our study contributes to the entrepreneurship spin-off literature by highlighting why and when alliances matter for innovation performance of two very different categories of spin-offs, CSOs and PROs. This is a novel perspective, as prior studies have given only 
limited attention to the network strategies of spin-offs ${ }^{1}$ and up till now primarily focused on the issues of survival, growth and profitability of this type of new firms, overlooking the innovation dimension. Our analysis of networking strategies of spin-offs confirms that the consequences of the choice of alliances partner for a spin-off's innovation performance differ importantly depending on its background (i.e. corporate as opposed to university or public research).

The rest of the paper proceeds as follows. In the following section, we develop a small set of hypotheses that guide our research on the different effects of alliances of spinoffs with either large or small and medium sized partners and the expected different outcomes of alliances for CSOs and PROs. This is followed by a section in which we picture the industrial setting for our empirical research and outline our data, sample, and measures. Next, we present some descriptive statistics and we test our hypotheses and some additional related research questions by means of instrumental-variables Poisson models, a supplementary analysis, and some robustness checks. In the final section, we discuss our findings in light of the alliance and spin-off literatures and we outline some of the limitations of our research and possible topics for future research.

\section{THEORETICAL BACKGROUND AND HYPOTHESES}

The vast literature on alliances appears unanimous in emphasising the importance of alliances for a range of firms that operate in high-tech industries (Ahuja, 2000; Carayannis et al. 2000; Lavie, 2007; Rothaermel et al. 2004; Soh 2003). The biopharmaceutical industry is a prime example of a high-tech industry where in particular new firms, such as spin-offs, play an

${ }^{1}$ A partial exception is Löfsten and Lindelöf (2005) which does not distinguish between different types of partners. We thank an anonymous referee for pointing out the latter study. 
important role in inter-firm networks based on alliances (Roijakkers and Hagedoorn 2006; Ernst \& Young 2011). The continuing appeal of alliances in these industries may be understood from a number of perspectives, including achieving improved economies of scale and scope (Gomes-Casseres 1997), further specialization in newly discovered technology fields (Zidorn and Wagner 2012), obtaining external legitimation (Baum and Oliver 1991) and gaining access to tangible and intangible (complementarity) assets (Rothaermel 2001; Lerner and Merges 1998).

A more specific explanation resides in the observation that spin-offs that operate in pharmaceutical and biotechnology industries face an environment characterized by strong technology and market uncertainties (Santoro and McGill 2005; Senker and Sharp 1997), where many new chemical entities and proteins/peptides are developed but few are actually chosen. Recent data put the clinical success rate of pharmaceuticals and biopharmaceuticals at 13 and 32 percent, respectively (DiMasi et al. 2010, see also Bienz-Tadmor et al. 1992, for earlier data). Even so, only about 30 percent of the products that reach the marketplace eventually generate enough revenues to repay their R\&D costs (DiMasi and Grabowski 2012). Given this uncertain future, the formation of alliances may be seen as an important way for spin-offs and other new technology-based firms to hedge their R\&D investments (Mowery 1989; Hagedoorn 1993).

In addition, few, if any, spin-offs initially possess the broad range of technological capabilities needed to stay innovative across a broad set of products and services (Forrest 1990). Insofar as innovations are the lifeblood of high-tech industries, allowing firms to grow and increase market share and, ultimately, profits (Cooper 2001), it is not surprising that the lack of information on new technologies is regarded as one of the most critical internal obstacles to innovation (Galia and Legros 2004; de Leeuw et al. 2013). New firms such as spin-offs are therefore often prompted into inter-firm alliances by the need to gain access to 
other firms' knowledge-based resources (Alvarez and Barney 2001; Scholten, Omta, Kemp, and Elfring, 2015). With the growth in the number of alliances, the locus of innovation for firms, including spin-offs, is no longer located within a single firm but rather in the network of alliances in which that firm is located (Freeman 1991; Powell et al. 1996). A number of studies demonstrate that the participation of young, startup firms in alliances is indeed positively associated with a range of innovation indicators (Baum et al., 2000; Chen and Li 1999; Dowling and Helm 2006; Freel and Harrison 2006; Haeussler et al., 2012; George et al., 2002; Neyens et al. 2010; Shan et al. 1994; Stuart, 2000).

While in general we expect spin-offs, as a distinct type of a young, startup firm, to benefit in terms of increased innovation from their alliances with other firms, they might benefit differently, depending on whether they form alliances with rather dissimilar partners, i.e. with either large, well established, firms or with other small and medium sized firms (SMEs). In the literature, we see two opposed and well-supported views on the benefits for spin-offs and other small firms in forming alliances either with large firms or with SMEs.

One body of literature suggests that forming alliances with large incumbent firms fortify spin-offs' reputation in terms of the perceived quality of their technology. In addition, research also suggests that, compared to less prominent or small partners, there is higher willingness of large, incumbent partners to invest in alliances (Baum et al. 2000; Stuart 2000; Dacin et al. 2007; Rao et al. 2008; Walter et al. 2006). Most importantly, the endorsement of a technology's intrinsic value by large established firms has the potential of attracting other high-quality partners, which, in turn, can increase the access of a new technology-based firm, such as a spin-off, to critical resources and, in so doing, positively influence its innovation performance (Dacin et al. 2007). Stuart (2000) in his study on new technology-based firms in the semiconductor industry, reports that alliances with well-known and larger firms play a significant role in building confidence in the value of young and small firms' product and 
services, thereby facilitating their endeavors to attract other corporate partners and, ultimately, innovate. In another example, Baum et al. (2000) show that dedicated biotechnology firms, such as biotech spin-offs, that form alliances with prominent pharmaceutical firms displayed better rates of patenting activity than those forming alliances with other small biotech firms. In line with the latter study, Haeussler et al (2012) found that the alliances of new biotech firms with other new small firms offer few if any opportunities for new product development, although the effect of these alliances on innovation performance is somewhat mitigated by the degree to which the new firm has specialized technological capabilities. In sum, this particular perspective on alliances between small firms, such as spin-offs, and either large firms or SMEs suggests the following hypothesis:

H1a. In terms of their innovation performance, spin-off firms benefit more from alliances with large firms than from alliances with small and medium-sized firms.

Interestingly, there is also an opposing view that highlights risks that small firms, such as spin-offs, face in partnering with large firms and that describes these alliances in terms of metaphors such as 'dancing with elephants' (Perez et al. 2012), 'dancing with gorillas' (Prashantham and Birkinshaw 2008) and 'swimming with sharks' (Katila, et al. 2008). Alvarez and Barney (2001) estimate that the probability that a small firm - large firm alliance will be unsuccessful may be even as high as 80 percent, with many of the small firms involved having to declare bankruptcy following the alliance failure. Rosenbusch et al. (2010), who conducted a meta-analysis to review 42 empirical studies, suggest that the internal innovation development projects of small firms are more productive than those projects that involve alliances with larger firms. Similarly, a longitudinal study of alliances in the U.S. motion picture industry carried out by Vandaie and Zaheer (2014) indicates that large partners diminish the positive effect of internal capability on the growth of small, independent studios. 
The literature suggests a range of explanations as to why alliances with large established partners do not always meet the expectations of new technology based firms such as spin-offs. Some studies state that convergence of purpose stemming from cultural distance and technological uncertainty stand in the way of successful asymmetric alliances between firms of very different size (Doz 1988; Tripsas et al. 1995). Others cite the poor communication between two very different 'species': whereas larger firms feature multiple 'layers' in their organizational structure and explicit processes for every task, small and newly established firms comprise generalists who generally use informal processes for getting things done (Botkin and Matthews 1992; Kelly et al. 2000; Prashantham and Birkinshaw 2008).

In general, the understanding of asymmetric alliances boils down to the basic idea that large firms might often leverage their bargaining power and extract a disproportional share of the benefits (Khanna et al. 1998; Bessy and Brousseau 1998; Kishida 2002; Lavie 2007). Nowhere is this more evident than in exploratory alliances, motivated by the desire to discover new opportunities (Koza and Lewin 1998), where firms face constant value allocation renegotiations about intellectual property rights and innovation benefits of newly discovered technologies that were impossible to foresee at the outset (Rothaermel and Deeds 2004; Yang et al. 2014). In that context, new firms, such as spin-offs, that often lack the experience associated with managing alliances, are disadvantaged vis-à-vis their large alliance partners (Rosenbusch et al. 2011; Yang et al. 2014). Obviously, these disadvantages are less decisive in alliances of spin-offs with SMEs where both partners face a more similar level playing field. As such this rather different perspective suggests the following alternative hypothesis:

H1b. In terms of their innovation performance, spin-off firms benefit more from alliances with small and medium-sized firms than from alliances with large firms. 
So far, we discussed spin-offs and the innovation performance implications of their alliances in terms of different alliance partner's size categories. However, the literature on spin-offs suggests there are also some major differences between CSOs and PROs, as CSOs seem to economically outperform PROs (Stankiewicz 1994; Lindholm-Dahlstrand 1997; Callan 2001; Tübke 2005; Ensley and Hmieleski 2005; Mustar et al. 2008; Yagüe-Perales and March-Chordà 2012; Zhang 2009; Wennberg et al. 2011). This advantage of CSOs over PROs begs the question as to what factors cause these advantages and to what extent they impact the innovation performance of the alliances in which these different categories of spin-offs engage. From a general perspective, the answer to this question can be related to the imprinting argument set forward by Stinchcombe (1965): organizations carry the legacy of their founding conditions. In the context of spin-offs, the argument is as follows: CSOs outperform non-CSOs, such as PROs, because their founding team members exhibit different 'genetic' characteristics in the form of prior business experience (Dahl and Reichestein 2007; Zahra et al. 2007; Andersson and Klepper 2013). In other words, spin-offs do not start their existence with clean slates; instead, they inherit the congenital knowledge of their entrepreneurial founders (Boeker 1989; Unger et al. 2011). PROs are less successful, with fewer prospects for growth and survival than CSOs, because their founders often lack the social capital required to secure external financing (Hirai et al. 2013; Shane and Stuart 2002) as well as the business acumen necessary to bring new products to markets (LindholmDalhstrand 1997b). According to Colombo and Piva (2012) founders of PROs seldom held previous managerial positions in other firms. These authors also find that academic founders that lack managerial experience are less likely than their peers from other spin-offs to make adequate commercial investments. In addition, Geenhuizen and Soetanto (2009) reveal that another important obstacle to growth facing PROs, such as academic spin-offs, is their lack of marketing knowledge. 
Agarwal et al. (2004) underscore the crucial role played by parental knowledge in linking the greater success of CSOs, compared to PROs, to better initial technological and market pioneering capabilities of their founders. Extending the imprinting argument, Zahra et al. (2007) suggest that the superior performance of CSOs, compared to that of PROs, is also related to their founders' abilities to maintain and continue using a range of business relationships. Not only the connections and networks of alliances that the founders of a CSOs inherit at inception of new ventures significantly enhance the ability of CSOs to transform knowledge into valuable products. Recent entrepreneurship research found that the ability of effective strategy formulation will vary by founder's identity and prior experience (Fauchart and Gruber 2011; Casper and Storz 2015). Careful identification of the 'right' alliance partners is not a trivial task and is considered as one of the keys for successful alliance strategy by new ventures (Greve, Rowley, Shipilov 2014; Walter et al. 2006). Given these findings, we expect that the corporate or academic backgrounds of the founders of CSOs or PROs have an enduring impact on the strategic choices of new firms such as the choice of particular alliance partners.

In sum, given that the CSO founders' contacts and previous networks are more varied, business-related, and valuable compared to those of PROs, compounded with superior technological, market pioneering as well as network strategy-formulation capabilities of CSOs, we expect that, compared to PROs, CSOs are better able to benefit from their interfirm alliances. Hence:

H2. In terms of their innovation performance, corporate spin-offs benefit more from alliances with other firms than public research spin-offs. 


\section{METHODS}

\section{Industry setting}

The industry setting for our study is found in the field of combinatorial chemistry, for which the period that we study in the context of alliance formation (1990-2003) marks the crucial shift from its very early emerging state to a first stage of some maturity (Thomke and Kuemmerle 2002). It is important to note that over time, the term 'combinatorial chemistry' has taken different meanings, leading to some degree of misunderstanding and even confusion (Lebl 2002). For some, it refers solely to the split-mix method, arguably the first combinatorial synthesis technology developed by Arkad Furka at Eötvös University in Budapest in 1982. For others, including the International Union of Pure and Applied Chemistry (IUPAC), the term denotes any process used “ ... to prepare large sets of organic compounds by combining sets of building blocks ...” (Maclean et al., 1999: 2351). This broader definition encompasses more than a dozen techniques, ranging from parallel synthesis to click chemistry, and it reflects the industry and technology setting that is subject to our study.

Virtually all process innovations related to combinatorial chemistry originated in academic laboratories and other PROs, including the Central Veterinary Institute in the Netherlands (parallel synthesis), University of Cambridge (diversity-oriented synthesis), Torrey Pines Institute for Molecular Studies (the 'tea-bag' procedure), the German National Research Center for Biotechnology (SPOT synthesis), and Scripps Research Institute (click chemistry). Over time, university researchers, professors, and other public sector researchers coming from the chemistry discipline jumped on the combinatorial bandwagon, launching spin-offs in the United States (e.g. Richard Houghton at the Torrey Pines Institute for Molecular Studies formed Houghton Pharmaceuticals), Great Britain (e.g. Steve Davies from Oxford University launched Oxford Asymmetry), France (e.g. Thierry Jean resigned from the 
CNRS to establish Cerep) and Denmark (e.g. Glenn Tong from the Technical University of Denmark co-founded AudA Pharmaceuticals).

However, the industry is not exclusively populated by PROs. Established in 1988, Affymax and Coselco Mimotopes were the first two new technology-based firms set up to engage in combinatorial chemistry research. Palo-Alto based independent start-up Affymax was the brainchild of Alejandro Zaffaroni - the quintessential Schumpeterian entrepreneur, legendary for having launched several successful firms (notably Syntex, Alza, and DNAX). Coselco Mimotope was established as a CSO from Commonwealth Serum Laboratories, Australia's largest biotech firm. This later case was not unique. Many other firms have also spun off start-ups with a competence in combinatorial chemistry: e.g. GlaxoSmithKline spun out NiKem Research; Hoffman LaRoche, Basilea Pharmaceuticals; Scios, Guilford Pharmaceuticals; Affymax, Affymetrix and Maxygen. In addition, manufacturers of scientific instrumentation (e.g. Advanced ChemTech), computational chemistry suppliers (e.g. Tripos) and, most commonly, biotechnology firms (e.g. Oxford Glycosciences, Vertex Pharmaceuticals) that were seeking to diversify their technology portfolios, also entered into this field.

\section{Data and sample}

We test our hypotheses on a longitudinal data set composed of 135 spin-offs operating in the combinatorial chemistry industry. Technology class information was used to make an initial identification of spin-offs with a clear competence in combinatorial chemistry. Each firm had to be endowed with at least one 'Class 506' patent (which is a special subclass created by the USPTO for inventions in the domain of combinatorial chemistry technology) or have a 
scientific publication in that field ${ }^{2}$. We then applied the following three criteria to the initial selection: the firm had to be 1) publicly traded so as to allow the collection of $R \& D$ expenditures data, 2) established as either a PRO or a CSO, and 3) commercially active between 1990 and 2003. Following Thomke and Kuemmerle (2002), this timeframe represents a particularly interesting period to examine as it largely captures the rapid emergence of combinatorial chemistry and its most dynamic phase of industrial technological development.

Reviewing the spin-off literature, we found no unifying consensus of a practical definition of either PROs or CSOs (Iacobucci et al 2011). In order to remove the ambiguity involved with identifying different types of spin-offs, we adopted the OECD definition of PRO. Accordingly, the term is defined as any new firm 1) of which the key technology is licensed from a university or another PRO, 2) which includes a university or public sector employee as a founder, and/or 3) in which a PRO has made an equity investment (Callan 2001). A CSO, by contrast, refers to any independent entity founded on the basis of a technology and human capital originating from a parent firm (Lindholm-Dalhstrand1997b). Guided by these considerations, we were able to identify 98 public research-based spin-offs (PROs) and 37 corporate spin-offs (CSOs) among our sample firms. Some 104 firms are located in the United States, while the remaining firms are established in eleven EU countries, primarily in Sweden, Great Britain, and Germany, as well as in Canada.

We collected data from a variety of sources. Alliance records were compiled from the Recombinant Capital, a health care data company, owned by Deloitte Consulting and from the websites of the sample spin-offs. In the present study, we consider all alliances that were established between 1990 and 2003 and which include licensing agreements, R\&D contracts,

2. For an examination of the process of creating a new patent category for combinatorial chemistry within the International Patent Classification (IPC), see Kang (2012). 
R\&D pacts, minority holdings, distribution or manufacturing agreements, asset trading, joint ventures, and consortia. From the two data sources we were able to identify some 3048 alliances undertaken by the sample firms in the period during which we calculate (lagged) alliance measures using a 3-year window. Alliances are differentiated into those between spin-offs and large firms (1284 alliances in total), those between spin-offs and SMEs (1184 alliances in total), alliances between spin-offs and PROs (524 in total) and alliances between spin-offs and their parent firms (56 in total). We retrieved information on patents, to construct our measure of innovation performance, from the Technology Profile Report maintained by the U.S. Patent and Trademark Office (USPTO). Our measure is based on granted patents, an indication of successful patent applications that we subsequently assigned to a particular application year. Data on firm-level variables, such as R\&D expenditures and the number of employees of US firms were obtained from SEC data at sec.gov., similar data for non-US firms were obtained from annual reports and firm websites.

\section{Measures}

Dependent variable. We use an invention (patent) count as our measure of spin-off's innovation output. Insofar as firms were engaged in a broad spectrum of research activities, patent data not only include patents in 'Class 506', but also those related to technologies other than combinatorial chemistry, as for example 'Class 435' (molecular biology and microbiology). Patents are typically regarded as among the most effective source of information for research on innovation and have been widely used as an indication of firm innovation (Sampson, 2007). One of their key advantages is reliability and objectivity because new inventions are cross-examined whether they satisfy criteria of novelty by patent officers at the U.S. Department of Commerce. The caveats of using patent data as a proxy for innovativeness are well known: not all innovations are patented, and those that are do display 
a great deal of variability in terms of value or importance (Pavitt 1985; Griliches 1990). The dependent variable is measured in year $t+1$ with respect to the right-hand-side variables.

Focal independent variables. Alliances are measured as the number of alliances established by the firm in the years $t-2$ through $t$ as constituting its alliance portfolio (i.e. cumulative sum over three years prior to the measurement of the dependent variable). Alliance data precede patent data for two reasons. First, learning from alliance partners is not automatic; it requires commitment, resources and, not least, time (Bierly and Chakrabarty 1996). Second, a gestation lag naturally separates the start of an alliance and the output of innovative activity (Stuart 2000). For the purpose of this study, a large firm alliance is defined as an alliance with a partner firm of more than 500 employees (more than twice the average size of a spinoff) whereas a SME partner has fewer than 500 employees.

Control variables. We control for alliances that spin-off firms formed with PROs and with their own parent firms. These two variables are constructed in the similar way as the focal variables. Research shows that alliances between industry and universities intensified in the 1990’s (e.g. Hall et al., 2003). Public science is attractive for firms because it provides low cost access to new knowledge and recent scientific developments. Alliances with parent firms may serve the purpose of strengthening a newly established firm's reputation and the perceived quality of its technology and provide a newly establish venture with resources.

The R\&D expenditures (measured in log of US dollar value) variable accounts for variation in inputs into the innovation process (Griliches, 1990). R\&D activities are expected to be a vital instrument in the innovation process and these activities are also expected to eventually be transformed into patents, certainly in a high-tech and patent-driven sector such combinatorial chemistry. In addition, higher levels of internal R\&D activities of firms can also be seen as a signal of valuable R\&D capabilities to potential alliance partners. 
Firm size (the logarithm of the number of firm employees) is a standard control variable in innovation studies and refers to the classical Schumpeterian understanding of the impact of firm size, through economies of scale and scope, on innovative performance in general and patenting activity, in particular (see also Belderbos, et al., 2006).

We also control for the technological diversification of spin-offs that can affect both innovation output and alliance activities of firms due their technological flexibility (Bierly and Chakrabarty, 1996). Technological diversification refers to the distribution of patents in a firm's patent portfolio over technology classes. Technology class information comes from the patent classes into which patents are assigned. To construct the diversification measure we distinguished between 243 unique 3-digit patent classes. We use a standard Shannon-Wiener diversity index to measure technological diversification, i.e. $T x=\sum_{i} p_{i} \log 1 / p_{i}$ where $i$ stands for any patent class. Obviously, a firm that has been granted patents in different patent classes will have a greater diversification index than a firm with patents in a single patent class. In addition, all models include unreported year dummies.

\section{RESULTS}

Some descriptive statistics and correlations are presented in table 1. We have predominantly small firms in our sample of spin-offs with a mean of about 180 employees. Average alliance portfolio size is about seven alliances, based on a 3-year cumulative sum, including alliances with PROs and parent firms. The latter two types are not very frequent in our data, with sample average of 1.07 and 0.16 , respectively. Pairwise correlations among the variables used in the estimation are moderate in most cases, with two exceptions. This includes the correlation between firm size and $R \& D$ and between alliances with large firms and SMEs. We show that any estimated effect of these two alliance variables is not due to potential (spurious) correlation, by also estimating models with only one of these variables included. 
The mean variance inflation factor (VIF) for the variables used in our models is about 2.6, which is below the commonly used threshold of 10 (Cohen et al. 2003).

Insert Table 1 about here

From the early until late 1990s we observe among the sample firms a strong upward trend in the alliance formation that flattens in 1998-1999 (see figure 1). This in turn is followed by a strong recovery around the turn of the century and a further dip after the technology crisis. The upward trend is more pronounced among the PROs than CSOs (see figure 2). Overall, these trends are consistent with those documented in Roijakkers and Hagedoorn (2006) and Schilling (2009).

The composition of these alliances is largely similar in the two types of spin-offs, suggesting that variation of innovation performance across spin-offs cannot be linked, for instance, to variation in the number of $R \& D$ contracts (see figures $3 a$ and $b$ ).

Insert Figures 1, 2, 3a and b about here

In the estimation of our models we seek to control for unobserved heterogeneity and potential endogeneity of the focal variables. Regarding the former, we argue that a core part of unobserved firm heterogeneity will be fixed, given the relatively short time span of our analysis. A number of firm traits, such as their CSO or PRO nature, founding team's demographic traits, and the nature of human capital will not change or change little over time. In our empirical models we control for such influences by including firm fixed effects.

A second potential source of endogeneity is the formation of alliances (over time). Alliance formation may be not be completely exogenous if this is driven by other endogenous concerns such as the search for technological variety or if alliance formation is dictated by the relative ease or difficulty of attracting alliance partners. The latter may play a role if the more successful firms in terms of their patenting become systematically more attractive as alliance partners. 
We sought to address the above concerns by conducting estimation of our model via instrumental variables (IV) and fixed-effects Poisson regression methods. ${ }^{3}$ In the IV GMM approach, we instrument alliances with other firms, alliances with large firms and SMEs, with their lagged values (measured in period t-3 to t-5) and a dummy variable indicating whether the firm is vested in the US or in the EU.

We present this analysis of the relationship between alliances and the innovation performance of spin-offs ${ }^{4}$ in table 1 and the non-instrumented versions of our fixed-effects count models in the Appendix. The GMM specification and the non-IV models produce consistent results while the Hansen test does not reject appropriateness of the instruments.

Regarding the control variables, we find, not surprisingly, that R\&D expenditures have the expected positive and significant effect on the innovation performance of spin-offs in this industry. The effect of the technological diversification of these spin-offs is significant in model I and model III.

Model I confirms our baseline understanding of a positive association of the number of inter-firm alliances of spin-offs and their innovation performance. In support of hypothesis 1a, we find that alliances of spin-offs with large firms have a positive impact on their innovation performance and, in rejection of the alternative hypothesis $1 \mathrm{~b}$, alliances with small firms have an insignificant impact on their innovative performance (see table 2, Model II). The difference between the two estimated coefficients is statistically significant $\left(\chi^{2}(1)=\right.$

3. Estimation of our models with the fixed-effects Poisson regression method implies that we cannot include any time-invariant variables, such as a dummy for the background of the firm or personal characteristics of the founder(s), in our models, since such a dummy always takes the same value during the estimation period. In the random effects specification of the Poisson model (not reported) we were able to estimate the coefficient of the dummy for the background of the firm, but we found that it is not statistically significant, implying that a spin-off's background does not directly determine our sample firm's innovation performance. 5. From the original sample of 135 firms, nine firms report zero patents during the estimation period and one firm has only one observation and hence these firms are dropped from the Poisson fixed-effects regression. Four of these firms are CSOs and six are PROs. 
4.34, p-value $=0.03$ ). In support of hypothesis 2 , in terms of their innovation performance, CSOs benefit more from alliances with other firms than PROs (see Table 2, Model III). The difference between the two estimated coefficients is again statistically significant $\left(\chi^{2}(1)=\right.$ 12.84, p-value $=0.00)$.

\section{Supplementary analysis}

In addition to testing the hypotheses and in further consideration of the role of alliance partners of different firm sizes, we also explored whether spin-offs, in terms of either CSOs or PROs, benefit more from having alliances with large firms or with SMEs (see table 2, model IV). In line with some previous studies (Baum et al. 2000; Stuart 2000), we find that both CSOs and PROs improve their innovation performance if they cooperate with large firms. The difference between the two estimated coefficients is not statistically significant. Interestingly, our findings also suggest that, in particular for PROs, alliances with SMEs have a negative impact on their innovation performance (see table 2, model IV).

The logic behind hypothesis 2 would suggest that, contrary to CSOs, PROs may actually benefit more from alliances with other PROs with which they share a common background. We explored this by estimating an additional regression (not reported) in which we interacted PRO alliances with the spin-off dummy. The PRO alliances of PROs are indeed positive and significant in a random effects Poisson model (and marginally insignificant in the fixed effects model), while the effect for CSOs is negative and marginally significant.

\section{Robustness checks}

To test the robustness of our findings we estimated a number of alternative specifications of our model. We explored the models with an alternative alliance variable, that is, calculated using a 5-year window, to examine a potential influence of longer lags on firm's patent output. These results are largely in line with those obtained from the reported models using a 
3-year window. One notable exception is the coefficient on alliances by PROs, which becomes marginally significant. However, in line with hypothesis 2 , the coefficient on this variable is statistically significantly smaller than that for the CSOs. This may suggest that the positive innovation performance effects of inter-firm alliances are slower to gestate among PROs than among CSOs.

To test whether the underlying main effects of alliance variables are non-linear, we considered models with the square terms of the three alliances variables included. However, none of these square terms are statistically significant. Inclusion of the square terms also makes the linear terms insignificant, hence we can rule out non-linearity.

\section{DISCUSSION AND CONCLUSIONS}

As the combinatorial chemistry industry emerged and reached its phase of early maturity, spin-offs in this field were bracing for serious challenges presented by a globalizing environment that is characterized by a fast pace of technological change (Malo and Geuna 2000). In order to survive in this environment, these firms needed to initiate shrewd alliance strategies (Mohr et al. 2014). Interestingly, it seems that this is exactly what spin-offs in the field of combinatorial chemistry did during the period 1990 - 2003. Specifically, as also demonstrated through Figures 1 and 2 show, their level of engagement in alliance activity steadily increased during the larger part of that early period. As reported in the above, this increase in alliance formation in the early period of the combinatorial chemistry industry is in line with the general alliance formation trend across a wider range of industries.

In the context of that general trend, there is an established literature on the innovation performance effects of alliances in high-tech industries, and in biotechnology industry in particular (e.g., Baum et al. 2000; Kim 2012; Rothaermel et al. 2004; Stuart 2000; Soh 2003; Sorrentino and Garrafo 2010). In this paper, we contribute to this literature by examining the 
relative effectiveness of alliance strategies for spin-offs - a specific type of young, technology-based firms - in affecting their innovation performance. We developed hypotheses that aimed to examine how the innovation performance of spin-off firms can benefit from inter-firm alliances with different categories of firms such as large firms or small and medium sized partners, a topic on which extant literature is still rather contradictory. We also contribute to the entrepreneurship literature on spin-offs by examining the innovation performance effects of alliances for both CSOs and PROs as two major categories of spinoffs with disparate corporate and public research backgrounds that we expect to benefit differently from their inter-firm alliances.

\section{Key Findings}

Our analysis clearly demonstrates that spin-off firms operating in a nascent industry can benefit from increasing numbers of alliances that positively affect their innovation performance. Given the relatively small number of alliances in which these spin-offs engage (see the descriptive statistics), the effect of decreasing returns to larger alliance portfolios and the effect of the relational mix of larger alliance portfolios (Wassmer, 2010) seems to be not that relevant in the current context. In addition to such a general finding, our study suggests a number of more specific novel insights related to the preference of spin-offs for particular partners and their corporate or public research background. First, during this early period of the combinatorial chemistry industry, inter-firm alliances with specific partners, in terms of their firm size, benefitted spin-offs in different ways. While alliances with relatively large partners generated benefits in terms of increased innovation performance, those with SME partners did not. In line with previous research, this finding suggests that spin-offs can benefit from alliances with large firms that bring superior alliance management capabilities to joint projects (Rothaermel and Deeds, 2006). These alliances with large firms also increase spin- 
offs' status and reputation that make it easier for these firms to attract other capable partners (Baum et al. 2000; Stuart 2000; Dacin et al. 2007; Rao et al. 2008).

Second, when looking at the background of spin-offs we see that during the emergence and early growth of the combinatorial chemistry industry, CSOs benefitted more from their inter-firm alliances than PROs. While both types of firms, CSOs and PROs, stand to gain from alliances with larger firms, PROs seemed to lose when they ally with SMEs, while such effect was neutral for CSOs. The greater benefits from inter-firm alliances for CSOs, compared to PROs, can be interpreted in light of the corporate or public research backgrounds imprinted in these spin-offs.

\section{Implications}

Our study contributes to spin-off and alliance research by highlighting how crafty selection of appropriate alliance partners, depending on the focal firm's background can foster spin-off's innovation. Specifically, our findings suggest that alliances do not have a unitary effect on innovation, and that spin-off firms are able to learn from their large partners and improve their innovation performance, despite the appropriation dangers that such asymmetric alliances potentially hold. On the other hand, spin-offs find fewer learning opportunities through alliances with SMEs. These smaller partners have somewhat comparable capabilities and hence are less likely to offer opportunities for advanced technology and product development similar to those offered by larger partners.

Our study contributes to the entrepreneurship literature in general by highlighting the importance of the venture's background. Previous studies on entrepreneurship indicate that the founding team's origins affect firm success (e.g., Cooper 1971; Eisenhardt and Schoonhoven 1990; Mangematin et al. 2003). One conclusion from prior studies is that in the context of PROs versus CSOs there is evidence that CSOs outperformed PROs in terms of return on assets and productivity, in large part because CSOs' founders had an advantage in 
using their prior experience, networks and connections (e.g., Benghozi and Salvador, 2014; Zahra et al. 2007). Our study demonstrates that similar advantages, in terms of prior experience, networks and connections, play a role in creating greater innovation performance benefits from a broad range of inter-firm alliances for CSOs compared to PROs. During the nascent state of the combinatorial chemistry industry the founding team members of CSOs were still connected to their corporate origins while PROs lacked these advantages and had fewer options but to search for alliances with more visible larger corporate partners.

\section{Limitations and future research}

Our study has a number of limitations, which at the same time suggest avenues for future research. First, our sample of a single industry could limit the generalizability of our findings. The role of different types of alliances for young, innovative spin-offs in different industrial settings is worth further investigation in light of renewed academic and policy interest for such firms (see Schneider and Veugelers, 2010).

Second, our empirical setting largely covers the emergence and gradual maturing of the combinatorial chemistry industry, a period characterized by high growth and high alliance activity of spin-offs. Further research could determine whether alliances continue to play a significant (positive) role as an industry further matures.

Third, as is the case with most innovation studies, we cannot fully exclude the possibility of reverse causality. Interestingly, a number of studies have examined a reverse relationship, i.e. the impact of firm's innovation on its alliance formation. For example, Ahuja (2000) concludes that innovativeness has a significant positive effect on alliance formation in the chemicals industry. Stuart (2000) and Podolny, Stuart and Hannman (1996) report similar findings in the semiconductor industry. The logic behind this relationship, using Ahuja's (2000) terminology, is that a firm's propensity to form alliances is determined by both 'inducements' and 'opportunities'. Innovative firms may have greater 'opportunities' 
to engage in alliances, because these firms are more attractive partners for joint technology development. On the other hand, high levels of technical and commercial expertise will reduce firms' 'inducement' to engage in alliances. As firms engage in alliances, successful innovative firms face a danger of involuntary dissipation of their knowledge to potential competitors, which can lead to weakening of their competitive advantage. Our research suggests that for resource inhibited spin-offs it is primarily positive 'inducements' that play an important role, thus mitigating the reverse causality logic. In addition, in an attempt to further minimize this possibility in the current analysis, we estimated our models with the instrumental-variables method.

Fourth, our analysis took into account the technological diversity of the firms in a broad sense, ignoring possible technological relatedness between dyads in a focal firm's alliances (Sampson, 2007). Further insights into an optimal alliance portfolio will require taking into account additional characteristics of alliance partners such as their knowledge base and the intensity of the collaboration. The interplay between the characteristics of the firm, such as its exploration or exploitation orientation, the characteristics of its alliance partners, the strategic fit of partners, and the impact of host countries could refine the model. Our analysis is largely macroscopic and could neither include potential organizational moderators nor assess the effect of the composition of the founding team on the effects of alliances on innovation performance. In our analysis, we attempt to mitigate this via fixed effects to control for team and firm-related time invariant unobservable characteristics and we encourage future research to further explore the micro-foundations of spin-offs' networking strategies.

\section{REFERENCES}


Agarwal, R., Echambadi, R., Franco, A., Sarkar, M.B. (2004) Knowledge Transfer through Inheritance: Spin-out Generation, Growth and Survival, Academy of Management Journal, 47: 501-522.

Ahuja, G. (2000) Collaboration networks, structural holes, and innovation: A longitudinal study, Administrative Science Quarterly, 45(3), 425-455.

Alvarez, S. A., Barney, J. B. (2001). How entrepreneurial firms can benefit from alliances with large partners, Academy of Management Executive, 15: 139 -148.

Andersson M., Klepper, S. (2013) Characteristics and performance of new firms and spinoffs in Sweden, Industrial and Corporate Change, 22: 245-280.

Archibugi, D., Michie, J. (1995) The globalisation of technology: a new taxonomy, Cambridge Journal of Economics, 19: 121-140.

Baum, J.A.C., Calabrese, T., Silverman, BS. (2000) Don't go it alone: alliance network composition and startups' performance in Canadian Biotechnology, Strategic Management Journal, 21: 263-294.

Baum, J.A.C., Oliver; C. (1991) Institutional linkages and organizational mortality, Administrative Science Quarterly, 36: 187-218.

Benghozi, P-J., Salvador E. (2014) Are traditional industrial partnerships so strategic for research spinoff development? Some evidence from the Italian case. Entrepreneurship \& Regional Development: an International Journal, 26 (1-2): 47-79.

Bessy, C., Brousseau, E. (1998) Technology Licensing Contracts: Features and Diversity, International Review of Law and Economics, 18: 451-489.

Bierly, P., Chakrabarti, A. (1996) Technological learning, strategic flexibility, and new product development in the pharmaceutical industry, IEEE Transactions on Engineering Management, 43: 368-380.

Bienz-Tadmor, B., DiCerbo, P., Tadmor, G., Lasagna, L. (1992) Biopharmaceuticals and conventional drugs: Clinical Success rates, Bio/Technology, 10: 521-525.

Boeker, W. (1989) Strategic change: the effects of founding and history, Academy of Management Journal, 32: 489-515.

Botkin, J.W., Matthews, J (1992) Winning Combinations: The Coming Wave of Entrepreneurial Partnerships Between Large and Small Companies, Wiley, NJ.

Callan, B. (2001) Generating spin-offs: evidence from the OECD, Science Technology Industry Review. Special Issue on Fostering High Tech Spin-Offs: A Public Strategy for Innovation, 26: 13-56. 
Carayannis, E. G., Kassicieh, S. K., Radosevich, R. (2000) Strategic Alliances as a Source of Early-Stage Seed Capital in New Technology-Based Firms, Technovation, 20: 603-615.

Casper, S., Storz, C. (2015) Comparative entrepreneurship: Social identity and strategy formulation in entrepreneurial firms, Academy of Management Proceedings doi: 10.5465/AMBPP.2015.17201

Chang, Y. C. (2003) Benefits of co-operation on innovative performance: evidence from integrated circuits and biotechnology firms in the UK and Taiwan, $R \& D$ Management, 33: 425-437.

Chen, R., Li, M. (1999) Strategic alliances and new product development: An empirical study of the U.S. semiconductor start-up firms, Advances in Competitiveness Research, 7: 35-61.

Clarysse, B., A. Heirman, J-J. Degroof, (2000) An institutional and resource based explanation of growth patterns of research based spin-offs in Europe in P.D Reynolds (Ed.), et al., Frontiers of Entrepreneurship Research, Babson College, 545-559.

Cohen, J., Cohen, P. C., West, S. G., Aiken, L. S. (2003). (3rd Ed.) Applied multiple regression/correlation analysis for the behavioral sciences. Mahwah, NJ.: Lawrence Erlbaum.

Colombo, M. G., Piva E., (2012) Firms' genetic characteristics and competence-enlarging strategies: A comparison of academic and non-academic high-tech start-ups, Research Policy, 41: 79-92.

Cooper, A.C. (1971) The Founding of Technologically-Based Firms, Milwaukee, WI: The Center for Venture Management.

Cooper, R. G. (2001) Winning at New Products: Accelerating the Process from Idea to Launch, 3rd Ed., Basic Books New York.

Dacin, M.T., Oliver, C. and Roy, J. (2007) The legitimacy of strategic alliances: an institutional perspective, Strategic Management Journal, 28:169-187.

Dahl, M., Sorenson, O. (2014) The who, why, and how of spinoffs, Industrial and Corporate Change 23 (3): 661-688.

Dahl, M., Reichstein, T. (2007) Are You Experienced? - Prior Experience of Managers and the Survival of New Organisations, Industry and Innovation, 14: 497-511.

DiMasi JA, Feldman L, Sechler A, (2010) Trends in risks associated with new drug development: success rates for investigational drugs, Clinical Pharmacology \& Therapeutics, 87: 272-277. 
DiMasi, JA, Grabowski, HG. (2012) R\&D Costs and returns to new drug development: a review of the evidence. In The Oxford Handbook of The Economics of the Biopharmaceutical Industry. eds. PM Danzon and S Nicholson, chapter 2:21-46. Oxford, UK: Oxford University Press.

Dowling, M., Helm, R. (2006) Product development success through cooperation: A study of entrepreneurial firms, Technovation, 26: 483-488.

Doz, Y. (1988) Technology partnerships between larger and smaller firms: some critical issues, International Studies of Management and Organisation, 17: 31-57

Eisenhardt, K. M., Schoonhoven, C. B. (1990) Organizational growth: linking founding team, strategy, environment, and growth among US semiconductor ventures, 1978-1988. Administrative Science Quarterly, 35: 504-529.

Ensley, M.D., Hmieleski, K.M. (2005). A comparative study of new venture top management team composition, dynamics and performance between university-based and independent startups, Research Policy, 34: 1091-1105.

Ernst \& Young (2011) Beyond borders Global biotechnology report 2010, New York; Ernst \& Young.

Forrest J.F. (1990) Strategic Alliances and the Small Technology-based Firm, Journal of Small Business Management, 28: 37-45.

Fauchart, E., Gruber, M. (2011) Darwinians, Communitarians, and Missionaries: The Role of Founder, Academy of Management Journal, 54(5), 935-957.

Freel, M., Harrison, R. (2006) Innovation and cooperation in the small firm sector: evidence from 'Northern Britain', Regional Studies, 40: 289-305.

Freeman, C. (1991) Networks of innovators: A synthesis of research issues, Research Policy, 20: 499-514.

Galia F., Legros D. (2004), Complementarities between obstacles to innovation: evidence from France, Research Policy, 33: 1185-1199.

Garvin, D. (1983) Spin-Offs and the New Firm Formation Process, California Management Review, 25: 3-20.

Geenhuizen, M. van, Soetanto, D.P. (2009) Academic spin-offs at different ages: A case study in search of key obstacles to growth, Technovation, 29: 671-681.

George, G., Zahra, S.A, Wheatley, K.K., Khan, R. (2001) The effects of alliance portfolio characteristics and absorptive capacity on performance: A study of biotechnology firms, Journal of High Technology Management Research, 12: 205-226. 
Golebiowski, S., Klopfenstein, R., Portlock, D. (2001) Lead Compounds Discovered from Libraries, Current Opinion in Chemical Biology, 5: 273-284.

Gomes-Casseres, B. (1997) Alliance Strategies of Small Firms, Small Business Economics, 9: $33-44$.

Greve, H., Rowley, T., Shipilov, A. (2014). Network advantage: How to unlock value from your alliances and partnerships, Wiley.

Griliches, Z. (1990) Patent Statistics as Economic Indicators: A Survey, Journal of Economic Literature, 28: 1661-1707.

Haeussler, C., Patzelt, H., Zahra, S.A. (2012) Strategic Alliances and Product Development in High Technology new firms: The moderating effect of technological capabilities, Journal of Business Venturing, 27: 217 - 233.

Hagedoorn, J. (1993) Understanding the Rationale of Strategic Technology Partnering Interorganizational Modes of Cooperation and Sectoral Differences, Strategic Management Journal, 14: 371-385.

Hall, B. H., Link, A. N., Scott, J. T. (2003) Universities as research partners, Review of Economics and Statistics, 85(2), 485-491.

Helm, R., Mauroner, O. (2007) Success of research-based spin-offs. State-of-the-art and guidelines for further research, Review of Managerial Science, 1: 237-270.

Hirai, Y., Watanabe, T., Inuzuka, A. (2013) Empirical analysis of the effect of Japanese university spinoffs' social networks on their performance, Technological Forecasting and Social Change, 80: 1119-1128.

Iacobucci D., Iacopini, A., Micozzi, A., Orsini, S. (2011), Fostering entrepreneurship in academic spin-offs. International Journal of Entrepreneurship and Small Business, 12 (4): $513-533$.

Kang, H.Y. (2012) Science Inside Law. The Making of a New Patent Class in the International Patent Classification, Science in Context, 25: 551-594.

Katila, R., Rosenberger, J., Eisenhardt, K. (2008) Swimming with sharks: Technology ventures, defense mechanisms and corporate relationships, Administrative Science Quarterly, 53: 295-332.

Kelly, M.J., Schaan, J.L., Jonacas, H. (2000) Collaboration between Technology Entrepreneurs and Large Corporations: Key Design and Management Issues, Journal of Small Business Strategy, 11: 60-76. 
Khanna, T., Gulati, R. Nohria, N. (1998) The dynamics of learning alliances competition, cooperation, and relative scope, Strategic Management Journal, 19: 193-210.

Kim, K.Y. (2012) Strategic R\&D alliance factors that impact innovation success in the biotechnology industry, International Journal of Technology Management, 59: 116-138.

Kishida, R. (2002) Strategic alliances between startups and large firms: Uncoupling entrepreneurial challenges. Paper presented at the annual meeting of the Academy of Management, Denver.

Klepper, S. (2009) Spinoffs: A review and synthesis, European Management Review, 6: 159171.

Koza, M.P., Lewin, A.Y. (1999) The co-evolution of network alliances: a longitudinal analysis of an international professional service network, Organization Science, 10: 255264.

Lavie, D. (2007) Alliance Portfolios and Firm Performance: A Study of Value Creation and Appropriation in the U.S. Software Industry, Strategic Management Journal, 28: 11871212.

Lebl, M. (2002) Combinatorial Chemistry. The history and basics, in H.Y Mei and A. W. Czarnik (Ed.), Integrated Drug Discovery Technologies, CRC Press, pp. 395-405.

Lechner, C., Dowling, M., and Welpe, I. (2006) Firm networks and firm development: The role of the relational mix. Journal of Business Venturing 21, 514-540.

Leeuw, de T., Podoynitsyna, K., Lokshin, B. (2013). Resource constraints, alliance portfolio diversity and innovative performance, Academy of Management Proceedings, 17210

Lejpras, A. and Stephan, A (2011) Locational conditions, cooperation, and innovativeness: evidence from research and company spin-offs, The Annals of Regional Science, 46: 543575.

Lerner, J., Merges, R. P. (1998) The Control of Technology Alliances: an Empirical Analysis of the Biotechnology Industry, Journal of Industrial Economics, 46: 125-56.

Lindholm-Dahlstrand, A. (1997) Growth and inventiveness in technology-based spin-off firms, Research Policy, 26: 331-344.

Lockett, A., Siegel, D.S., Wright, M., and Ensley, M. (2005). The creation of spin-off firms at public research institutions: Managerial and policy implications. Research Policy, 34, 981-993. 
Löfsten, H., Lindelöf, P. (2005) R\&D networks and product innovation patterns of academic and non-academic new technology-based firms on Science Parks, Technovation, 25: 10251037.

Maclean, D., Baldwin, J.J., Ivanov, V.T., Kato, Y., Shaw, A., Schneider P., Gordon, E.M. (1999) Glossary of Terms used in Combinatorial Chemistry, Pure Applied Chemistry, 71: 2349-2365.

Malo, S., Geuna, A. (2000) Science-technology linkages in an emerging research platform: the case of combinatorial chemistry and biology, Scientometric, 47: 303-321.

Mangematin, V., Lemarie, S., Boissin, J.-P., Catherine, D., Corolleur, F., Corolini, R. and Trommetter, M. (2003) Development of SMEs in France The case of biotechnology, Research Policy, 32: 621-638.

Mohr, V, Garnsey, E, Theyel, G (2014) The role of alliances in the early development of high-growth firms, Industrial and Corporate Change, 23: 233-259.

Mowery, D.C. (1989) Collaborative Ventures Between US and Foreign Manufacturing Firms, Research Policy, 18: 19-32.

Mowery, D.C., Oxley, J.E., Silverman, B.S. (1996) Strategic alliances and interfirm knowledge transfer, Strategic Management Journal, 17: 77-91.

Mustar, P., Wright, M., Clarysse, B. (2008) University spinoff firms: Lessons from ten years of experience in Europe, Science and Public Policy, 35: 67-80.

Neyens, I., Faems, D., Sels, L. (2010). The Impact of Continuous and Discontinuous Alliance Strategies on Startup Innovation Performance, International Journal of Technology Management, 52: 372-391.

OECD (2001) Special Issue on Fostering High-tech Spin-offs. A Public Strategy for Innovation Paris, STI Review No. 26, Organisation for Economic Co-operation and Development: Statistical Office of the European Communities.

OECD (2007). Intellectual Assets and International Investment: A stocktaking of the evidence. Report to the OECD Investment Committee DAF/INV/WD(2007)6, Paris, OECD.

Pavitt, K. (1985) Patent Statistics as Indicators of Innovative Activities: Possibilities and Problems, Scientometrics, 7: 77-99

Perez, L., Florin, J., Whitelock, J. (2012) Dancing with elephants: The challenges of managing asymmetric technology alliances, Journal of High Technology Management Research, 23: 142-154. 
Podolny, J.M., Stuart, T.E., Hannan, M.T. (1996) Networks, knowledge and niches: competition in the worldwide semiconductor industry, 1984-1991, American Journal of Sociology, 102: 659-689.

Prashantham, S., Birkinshaw, J. (2008) Dancing with gorillas: how small companies can partner effectively with MNCs, California Management Review, 51: 6-23.

Powell, W.W., Grodal, S. (2005) Networks of Innovators, in J. Fagerberg, D. C. Mowery, Nelson, R. R. (Eds.), The Oxford Handbook of Innovation, pp. 56-85.

Powell, W. W., Koput, K. W., Smith-Doerr, L. (1996) Interorganizational collaboration and the locus of innovation: Networks of learning in biotechnology, Administrative Science Quarterly, 41: 116-145.

Rao, R. S., Chandy, R. K., Prabhu, J. C. (2008) The fruits of legitimacy: Why some new ventures gain more from innovation than others, Journal of Marketing, 72: 58-75.

Roijakkers, N., Hagedoorn, J. (2006) Inter-firm R\&D partnering in pharmaceutical biotechnology since 1975: Trends, patterns, and networks, Research Policy, 33: 11531165 .

Rosenbuch, N.; Brinckmann, J.; Bausch, A . (2010) Is innovation always beneficial? A meta an a lysis of the relationship between innovation and performance in SMEs. Journal of Business Venturing, 26: 441 - 457,

Rothaermel, F.T. (2001) Incumbent's advantage through exploiting complementary assets via interfirm cooperation, Strategic Management Journal, 22: 687-699.

Rothaermel, F.T., Deeds, D.L. (2004) Exploration and exploitation alliances in biotechnology: A system of new product development, Strategic Management Journal, 25: 201-221.

Rothaermel, F.T., Deeds, D.L. (2006) Alliance type, alliance experience and alliance management capability in high-technology ventures, Journal of Business Venturing, 21: 429-460.

Sampson, R.C. (2007) R\&D alliances and firm performance: the impact of technological diversity and alliance organization on innovation, Academy of Management Journal, 50: 364-386.

Santoro, M., McGill, J. (2005) The effect of uncertainty and asset co-specialization on governance in biotechnology alliances, Strategic Management Journal, 26: 1261-1269.

Schilling, M. (2009) Understanding the alliance data, Strategic Management Journal, 30: 233-260. 
Schneider, C., Veugelers, R. (2010) On young highly innovative companies: why they matter and how (not) to policy support them, Industrial and Corporate Change, 19(4), pp. 9691007

Scholten, V., Omta, S.W.F., Kemp, R. and Elfring T. (2015). Interaction effects of start-up team capabilities and bridging ties on early spin-off growth. Technovation, 45-46: 40-51.

Sedaitis, J. (1998) The alliances of spin-offs versus start-ups: Social ties in the genesis of post-soviet alliances, Organization Science 9(3):368-381

Senker, J., Sharp, M. (1997) Organizational Learning in Cooperative Alliances Some Case Studies in Biotechnology, Technology Analysis and Strategic Management, 9: 35-51.

Shan, W., Walker, G., Kogut, B. (1994) Interfirm Cooperation and Startup Innovation in the Biotechnology Industry, Strategic Management Journal, 15: 387-394.

Shane, S. (2004) Academic entrepreneurship: university spinoffs and wealth creation. Elgar, Cheltenham.

Shane, S., Stuart, T. (2002) Organizational Endowments and the Performance of University Start-ups, Management Science, 48: 154-170.

Soh, P.H. (2003) The role of networking alliances in information acquisition and its implications for new product performance, Journal of Business Venturing, 18: 727-744.

Sorrentino, F., Garaffo, F. (2010) Explaining performing R\&D through alliances: evidences from Italian Dedicated Biotech Firms, Journal of Management \& Governance, 16: 449475 .

Spin-off Advisors (2014) Number of completed U.S. spin-offs by year. Retrieved from http://www.spinoffresearch.com/spin-off-mechanics/number-of-spin-offs/

Stankiewicz, R. (1994) Spin-off companies from universities, Science and Public Policy, 21: 99-107.

Stinchcombe, A. (1965) Social structure and social organization, in: March J (editor) The Handbook of Organizations, pp. 142-193.

Stuart, T. E. (2000) Interorganizational alliances and the performance of firms: A study of growth and innovation rates in a high-technology industry, Strategic Management Journal, 21: 791-911.

Thomke, S., Kuemmerle, W. (2002) Asset accumulation, interdependence and technological change: evidence from pharmaceutical drug discovery, Strategic Management Journal, 23: 619-35. 
Tripsas, M., Schrader, S., Sobrero, M. (1995) Discouraging opportunistic behavior in collaborative R\&D: A new role for government, Research Policy, 24: 367-389.

Tübke, A. (2005) Success Factors of Corporate Spin-offs, New York: Springer Science Business Media.

Unger, J.M., Rauch, A., Freser, M., Rosenbusch, N. (2011). Human capital and entrepreneurial success: A meta-analytical review. Journal of Business Venturing, 26341-358.

Vandaie, R., Zaheer, A. (2014) Surviving bear hugs: Firm capability, large partner alliances, and growth, Strategic Management Journal, 35: 566-577.

Walter, A., Auer, M. and Ritter, T. (2006) The impact of network capabilities and entrepreneurial orientation on university spin-off performance, Journal of Business Venturing, 21: 541-567.

Wassmer, U. (2010) Alliance portfolios: A review and research agenda, Journal of Management 36(1): 141-171

Wennberg, K., Wiklund, J., Wright, M. (2011) The effectiveness of university knowledge spillovers: Performance differences between university spinoffs and corporate spinoffs, Research Policy, 40: 1128 -1143.

Yagüe-Perales, R., March-Chordà, I. (2012) Performance analysis of research spin-offs in the Spanish biotechnology industry, Journal of Business Research, 65: 1782-1789.

Yang, H., Zheng, Y., Zhao, X. (2014) Exploration or exploitation? Small firms' alliance strategies with large firms, Strategic Management Journal, 35: 146 - 157

Zahra, S., Van Develde, E., Larrenta, B. (2007) Knowledge Conversion Capability and the Performance of Corporate and University Spin-Offs, Industrial \& Corporate Change, 16: 569-608.

Zhang, J. (2009) The performance of university spin-offs an exploratory, The Journal of Technology Transfer, 34: 255-285.

Zidorn, W., Wagner, M. (2013) The Effect of Alliances on Innovation Patterns: An Analysis of the Biotechnology Industry, Industrial and Corporate Change, 22: 1497-1524. 
Table 1 Descriptive statistics and pairwise correlations

\begin{tabular}{|c|c|c|c|c|c|c|c|c|c|}
\hline & Mean & SD & 1 & 2 & 3 & 4 & 5 & 6 & 7 \\
\hline 1. Patents & 6.96 & 15.48 & 1.00 & & & & & & \\
\hline 2. Firm size $(\log )$ & 4.63 & 1.14 & 0.38 & 1.00 & & & & & \\
\hline 3. $R \& D$ expenditures & 9.44 & 1.50 & 0.39 & 0.66 & 1.00 & & & & \\
\hline 5. Alliances with own parent firm & 0.16 & 0.48 & -0.07 & -0.11 & -0.12 & -0.04 & 1.00 & & \\
\hline 6. Alliances with PROs & 1.07 & 1.69 & 0.05 & 0.01 & 0.05 & 0.12 & 0.23 & 1.00 & \\
\hline 7. Alliances with large firms & 3.07 & 3.49 & 0.27 & 0.47 & 0.39 & 0.34 & -0.01 & 0.14 & 1.00 \\
\hline
\end{tabular}

Note. Correlations based on 929 observations for 125 firms. Correlations greater than .07 are statistically significant at an alpha level of .05 , and correlations greater than $|.05|$ are statistically significant at an alpha level of .01 . 
Table 2 Alliances and the innovation performance of corporate and public research spin-offs

\begin{tabular}{|c|c|c|c|c|}
\hline Variable & Model I & Model II & Model III & Model IV \\
\hline \multirow{2}{*}{ Constant } & $-4.195 * * *$ & $-5.625 * * *$ & $-4.241 * * *$ & $-5.406 * * *$ \\
\hline & $(0.504)$ & $(1.184)$ & $(0.522)$ & $(0.972)$ \\
\hline \multirow[t]{2}{*}{ Firm size } & -0.031 & -0.231 & 0.009 & 0.026 \\
\hline & $(0.119)$ & $(0.402)$ & $(0.107)$ & $(0.137)$ \\
\hline \multirow[t]{2}{*}{$\mathrm{R} \& \mathrm{D}$} & $0.504 * * *$ & $0.761 * * *$ & $0.489 * * *$ & $0.620 * * *$ \\
\hline & $(0.060)$ & $(0.210)$ & $(0.049)$ & $(0.081)$ \\
\hline \multirow[t]{2}{*}{ Technological diversification } & $0.446 * * *$ & -0.217 & $0.565 * * *$ & 0.127 \\
\hline & $(0.081)$ & $(0.482)$ & $(0.085)$ & $(0.286)$ \\
\hline \multirow[t]{2}{*}{ Alliances with own parent firm } & -0.031 & 0.161 & 0.020 & 0.165 \\
\hline & $(0.107)$ & $(0.162)$ & $(0.084)$ & $(0.119)$ \\
\hline \multirow[t]{2}{*}{ Alliances with PROs } & $-0.073 * *$ & -0.105 & $-0.098 * * *$ & $-0.118 * * *$ \\
\hline & $(0.035)$ & $(0.070)$ & $(0.031)$ & $(0.037)$ \\
\hline \multirow[t]{2}{*}{ Alliances with other firms } & $0.059 * * *$ & & & \\
\hline & $(0.019)$ & & & \\
\hline \multirow[t]{2}{*}{ Alliances with large firms } & & $0.258 * *$ & & \\
\hline & & $(0.110)$ & & \\
\hline \multirow[t]{2}{*}{ Alliances with SMEs } & & -0.071 & & \\
\hline & & $(0.074)$ & & \\
\hline \multirow[t]{2}{*}{ Alliances of CSOs with other firms } & & & $0.059 * * *$ & \\
\hline & & & $(0.016)$ & \\
\hline \multirow[t]{2}{*}{ Alliances of PROs with other firms } & & & 0.025 & \\
\hline & & & $(0.020)$ & \\
\hline \multirow[t]{2}{*}{ Alliances of CSOs with large firms } & & & & $0.093 * * *$ \\
\hline & & & & $(0.034)$ \\
\hline \multirow[t]{2}{*}{ Alliances of PROs with large firms } & & & & $0.187 * * *$ \\
\hline & & & & $(0.062)$ \\
\hline \multirow[t]{2}{*}{ Alliances of CSOs with SMEs } & & & & 0.048 \\
\hline & & & & $(0.044)$ \\
\hline \multirow[t]{2}{*}{ Alliances of PROs with SMEs } & & & & $-0.153 * *$ \\
\hline & & & & $(0.078)$ \\
\hline Hansen test, $\mathrm{p}$ (value) & $2.248(0.13)$ & $1.451(0.48)$ & $2.481(0.29)$ & $1.490(0.47)$ \\
\hline
\end{tabular}

Note: Results from fixed effects instrumental-variables Poisson models. Robust (clustered) standard errors in parentheses. $* p<0.1, * * p<0.05, * * * p<0.01$. All models are estimated on a sample of 929 observations for 125 firms and include 8 time dummies. The dependent variable is measured in year $t+1$ with respect to the righthand-side variables. The Hansen test statistic is the test of overidentifying restrictions. 
Figure 1 Spin-off alliance formation with large and small \& medium-sized firms by year

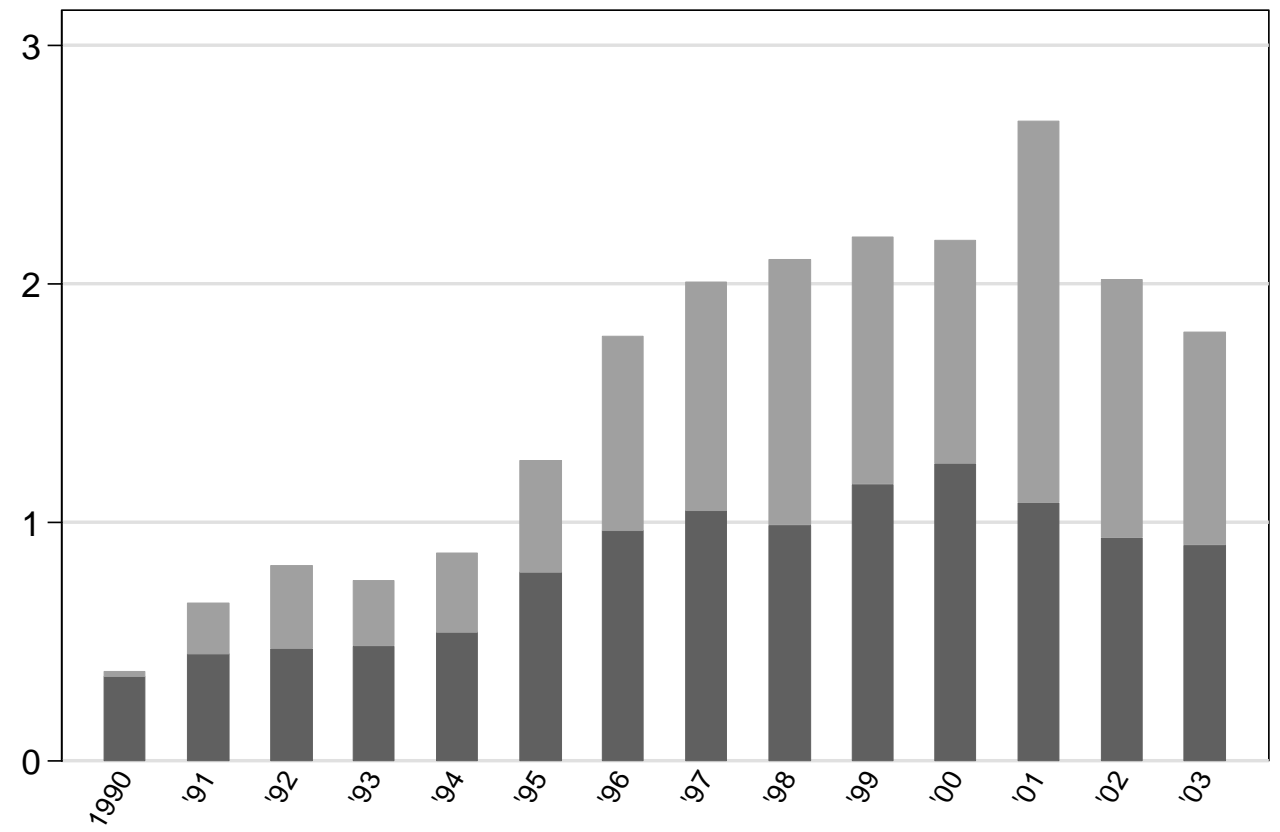


Figure 2 Spin-offs alliance formation by year and type of spin-off firm

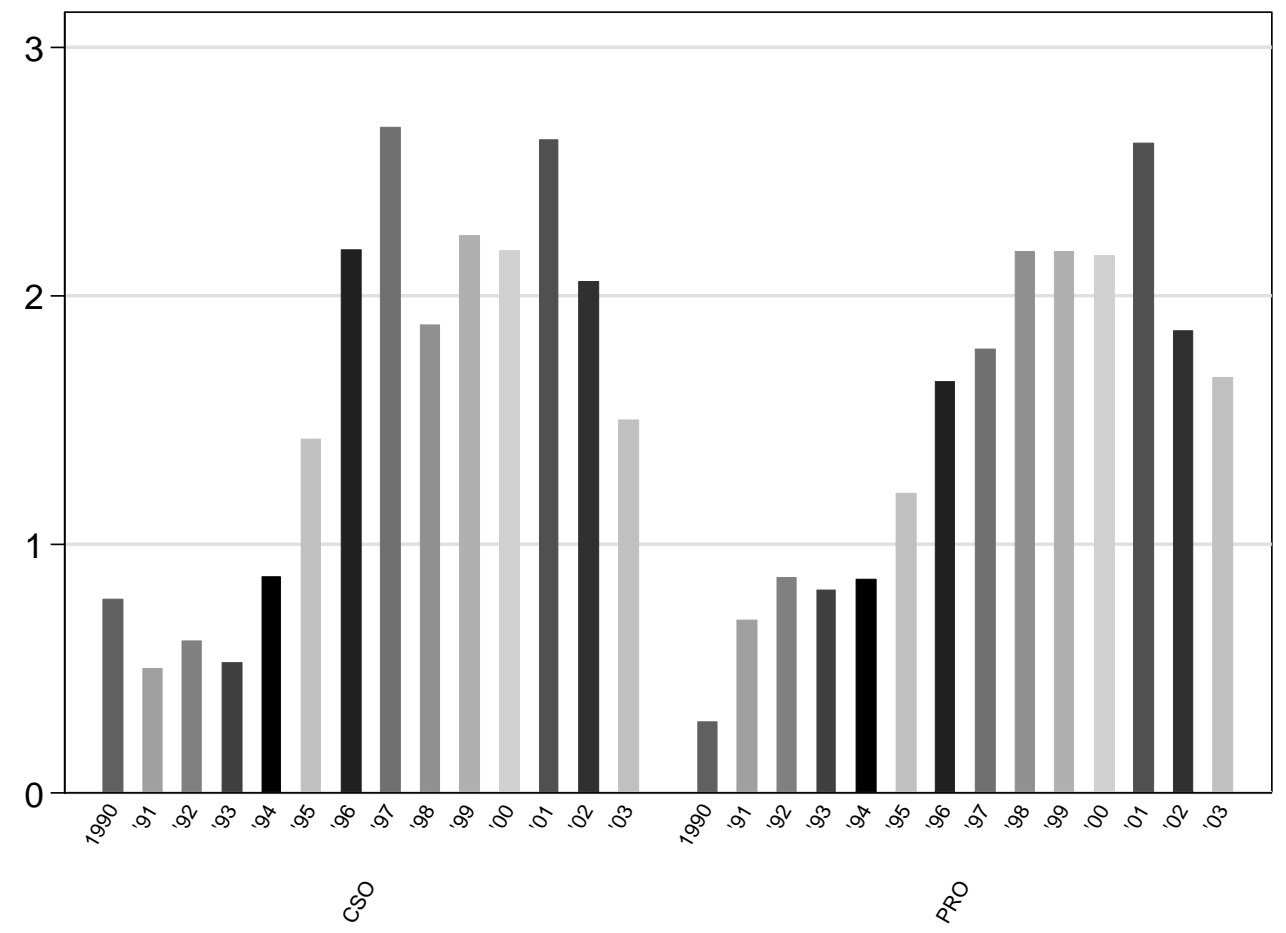


Figure 3a Distribution of R\&D alliances, licensing agreements, and other types of alliances for CSOs

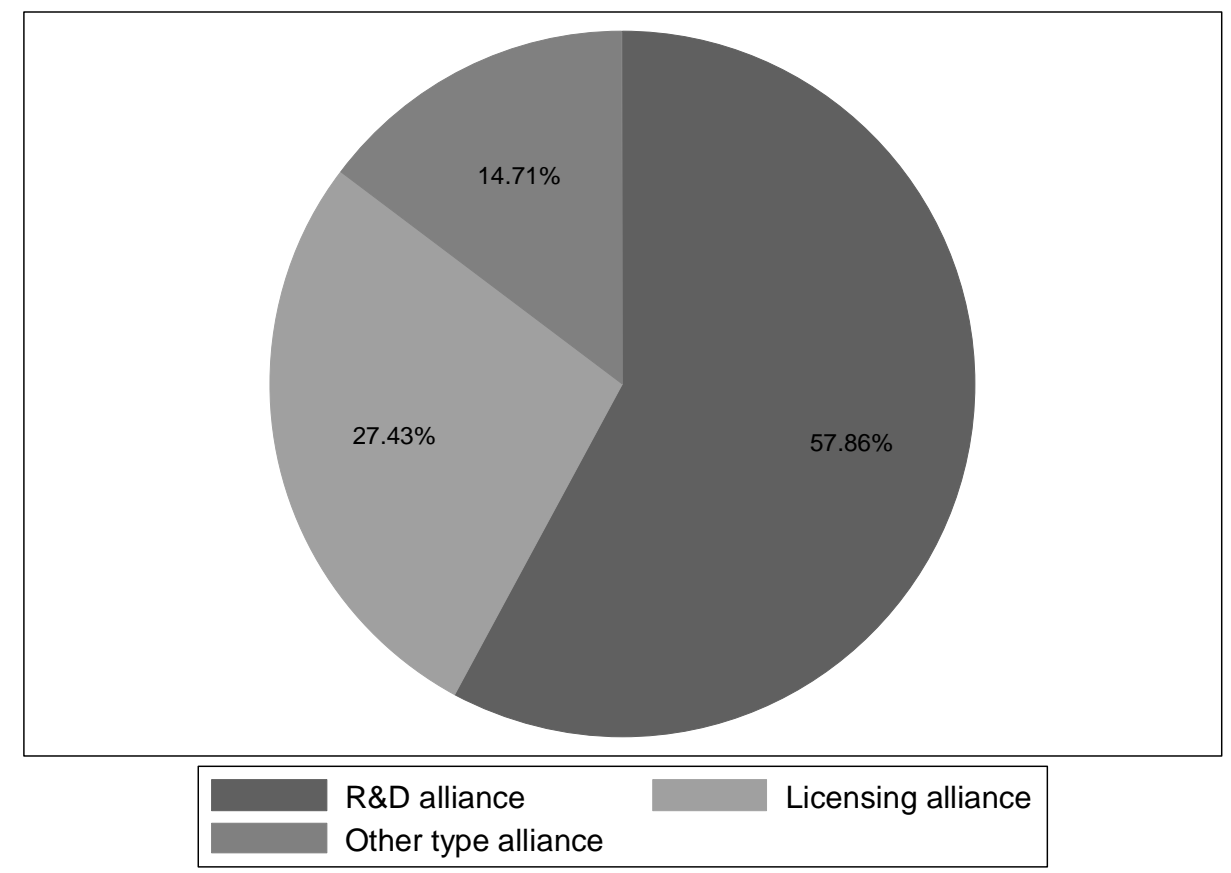

Figure $3 b$ Distribution of R\&D alliances, licensing agreements, and other types of alliances for PROs

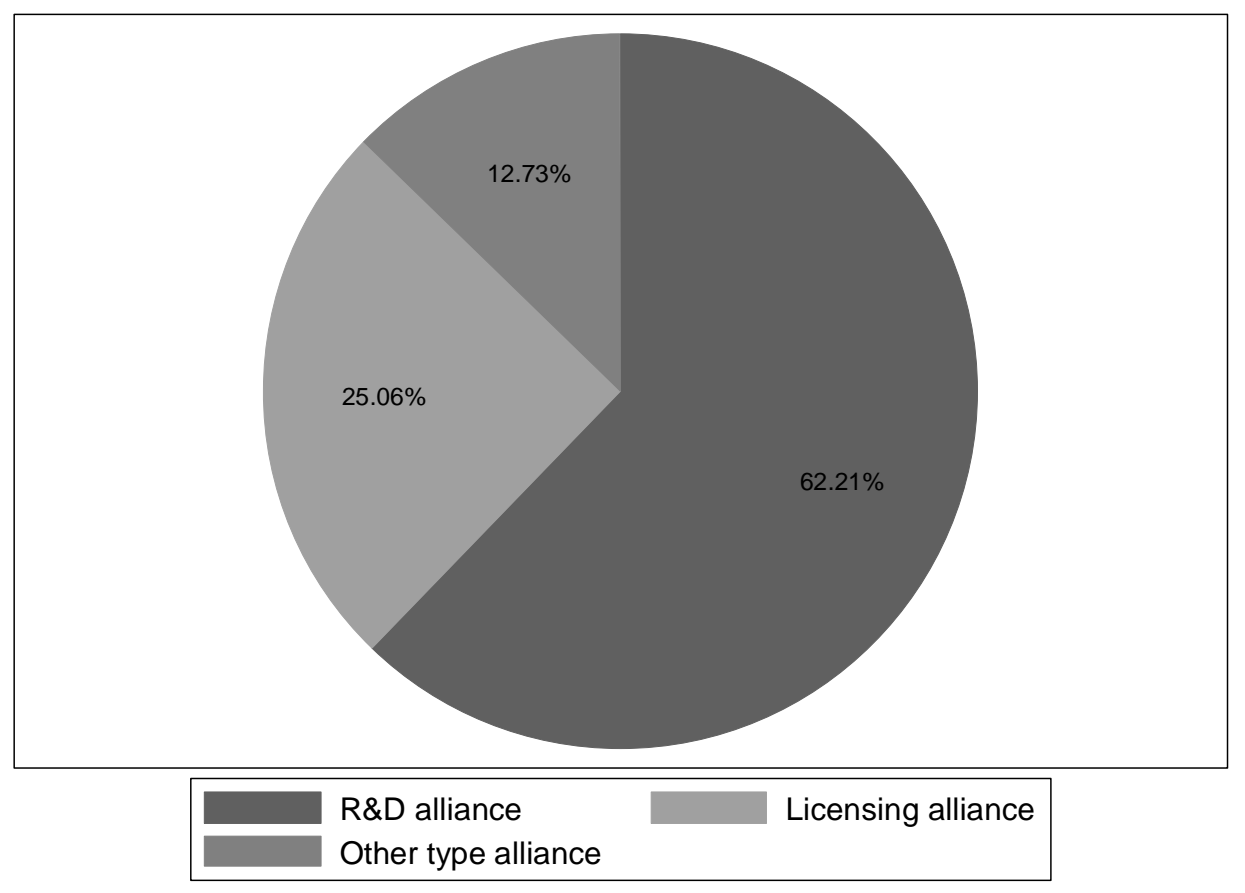




\section{APPENDIX}

Alliances and the innovation performance, fixed-effects Poisson without instrumental variables

\begin{tabular}{|c|c|c|c|c|}
\hline Variable & Model I & Model II & Model III & Model IV \\
\hline \multirow[t]{2}{*}{ Firm size } & 0.101 & 0.033 & 0.097 & 0.025 \\
\hline & $(0.204)$ & $(0.167)$ & $(0.202)$ & $(0.177)$ \\
\hline \multirow[t]{2}{*}{$\mathrm{R} \& \mathrm{D}$} & $0.225 * *$ & $0.252 * *$ & $0.236 * *$ & $0.256 * *$ \\
\hline & $(0.108)$ & $(0.109)$ & $(0.104)$ & $(0.112)$ \\
\hline \multirow[t]{2}{*}{ Technological diversification } & 0.198 & $0.216^{*}$ & $0.210 *$ & $0.222 *$ \\
\hline & $(0.123)$ & $(0.128)$ & $(0.120)$ & $(0.127)$ \\
\hline \multirow[t]{2}{*}{ Alliances with own parent firm } & -0.002 & 0.017 & 0.008 & 0.015 \\
\hline & $(0.119)$ & $(0.113)$ & $(0.115)$ & $(0.112)$ \\
\hline \multirow[t]{2}{*}{ Alliances with PROs } & -0.044 & -0.026 & -0.048 & -0.024 \\
\hline & $(0.041)$ & $(0.022)$ & $(0.041)$ & $(0.027)$ \\
\hline Alliances with other firms & $\begin{array}{c}0.026 * * * \\
(0.009)\end{array}$ & & & \\
\hline \multirow[t]{2}{*}{ Alliances with large firms } & & $0.081 * * *$ & & \\
\hline & & $(0.016)$ & & \\
\hline \multirow[t]{2}{*}{ Alliances with SMEs } & & $-0.035 * *$ & & \\
\hline & & $(0.014)$ & & \\
\hline \multirow[t]{2}{*}{ Alliances of CSOs with other firms } & & & $0.031 * * *$ & \\
\hline & & & $(0.008)$ & \\
\hline \multirow[t]{2}{*}{ Alliances of PROs with other firms } & & & 0.021 & \\
\hline & & & $(0.015)$ & \\
\hline \multirow[t]{2}{*}{ Alliances of CSOs with large firms } & & & & $0.085^{* * *}$ \\
\hline & & & & $(0.018)$ \\
\hline \multirow[t]{2}{*}{ Alliances of PROs with large firms } & & & & $0.074 * *$ \\
\hline & & & & $(0.030)$ \\
\hline \multirow[t]{2}{*}{ Alliances of CSOs with SMEs } & & & & -0.039 \\
\hline & & & & $(0.027)$ \\
\hline \multirow[t]{2}{*}{ Alliances of PROs with SMEs } & & & & $-0.031 *$ \\
\hline & & & & $(0.019)$ \\
\hline Log-likelihood & -2665.13 & -2570.98 & -2663.13 & -2570.42 \\
\hline$\chi^{2}$ test of improved model fit & & $188.29^{* * *}$ & $3.99^{* *}$ & $185.43^{* * *}$ \\
\hline
\end{tabular}

Note: Results from fixed effects Poisson models. Robust (clustered) standard errors in parentheses.

$* \mathrm{p}<0.1, * * \mathrm{p}<0.05, * * * \mathrm{p}<0.01$. All models are estimated on a sample of 929 observations for 125 firms and include 8 time dummies. The dependent variable is measured in year $\mathrm{t}+1$ with respect to the right-hand-side variables. The $\chi^{2}$ test statistic is the likelihood-ratio test comparing the focal model with the more parsimonious model 